\title{
Branding destinations with multisensory brand associations and evaluating its impact on behavioural pattern under the intervention of multiplex phenomenon of relationship-branding
}

\author{
Arup Kumar Baksi ${ }^{a^{*}}$ and Tapan Kumar Panda ${ }^{b}$
}

${ }^{a}$ Associate Professor, Dept. of Management \& Business, Administration, Aliah University, Kolkata, West Bengal, India ${ }^{b}$ Professor \& Dean, School of Management, O. P. Jindal Global University, Sonipat, Haryana, India

\section{CHRON I CLE A B T R A C T}

Article history:

Received: May 8, 2018

Received in revised format: June

24, 2018

Accepted: August 9, 2018

Available online:

August 14, 2018

Keywords:

Perceived destination brand

image

Multisensory

Relationship-branding

Post-travel behaviour

Intervening

\begin{abstract}
Image perception has been acknowledged as a critical component of branding. Perception of image is comparatively difficult for intangible entities like 'destination'. Research initiatives, thus far, has postulated destination branding on associations namely cognitive and affective image inputs. Multisensory brand associations were never tested for destination branding model, although, sensory brand associations were found to play major role in the tangible product branding and influence purchase behaviours. Further, attributional elements, specific to destination are assumed to play critical role in developing the brand identity leading to choice of destination. Perceived destination brand image was empirically tested for its influence on post-travel behaviours and was identified as one of the potent travel motives, however, the predictive capability of perceived destination brand image on favourable post-travel behaviours seems to fall off due to reasons unknown. Researchers like Fournier, observed that relationship-branding can induce favourable post-purchase behaviour. This study focuses on developing a destination brand model using conventional brand associations, namely cognitive and affective image inputs, and new associations, namely, attributional and sensory image inputs. The study further incorporates relationship-branding as a multiplex phenomenon and tested its possible intervening impact between perceived destination brand image and post-travel behaviours. The results established the destination brand model based on the image associations and confirmed the role of relationship-branding as a para-social and socio-emotional moderator to influence post-travel visitor behaviour. The study plugs in the gap that existed in the present body of knowledge addressing destination branding and reinforces the relationship theory in establishing the 'brand - purchase - post-purchase behaviour' triad.
\end{abstract}

\section{Introduction}

Branding of services represents the height of intangibility. Experiential services, namely tourism, therefore, has been grounded on visitors' evocation and choice of destination to shape into a brand (Tasei \& Kozak, 2006). Branded content, too, seems to play a role in the articulation of destination branding. The choice of destination depends on the extent to which they are differentiated on the basis of destinationspecific attributes (Pawaskar \& Goel, 2014) and its compatibility with the socio-emotional, ethno-cultural and socio-economical scaffold of the visitors (Qu et al., 2011). Therefore, branding of destination also seems to be influenced by attributional images.

* Corresponding author.

E-mail address: baksi.arup@gmail.com (A. K. Baksi) 
Perceived destination image, a reflection of preserved set of memories associating visitors with destination visited, has been identified as a major destination branding component (Cai, 2002; Pike, 2009). Therefore, destination image, thus far, has been constructed on the ground of this 'memory-association' comprising of perceived cognitive and affective images as sensory inputs (Hosany et al., 2007, Uysal et al., 2000) and is apprehended to be critical in branding destinations (Pike, 2009; Hosany et al., 2007; Baloglu \& Mangaloglu, 2001). Destination branding has been conceptualized as an integrated series of marketing tasks that reinforces the differentiation between destinations based on attributes, consolidates the expectations of a cherished travel experience, ensures the socio-emotional and ethno-cultural bonding between the visitor and the destination and diminishes the perceived risk associated with the travel (Blain et al., 2005). Studies by Chen and Phou (2013), Bove-Sans and Laguado-Ramírez (2013), Mariutti et al. (2013) indicated that destination attributes have impact on the formation of perceived destination image. With proliferation of brands the problem of clutter has thrown major challenges to the marketers to penetrate the crowd. Marketers are replacing the mass marketing strategy with customized and relationshipbased marketing, but, that too seems to be inadequate in the context of destination marketing. For years the sensory perceptions of the consumers (sight, sound, smell, touch and taste) have guided them towards selection and endorsement of brands, yet, they were largely neglected as constructs in sensory image building by the researchers. The individual sensory perception of a brand is a psychological projection of expectations from the same based on experience logic, which, essentially is configured by the human brain with simulation from five senses (Hulten et al., 2009). Lindstrom and Kotler (2005) observed that sensory inputs namely vision and sound influence brand perception. Subliminal perception has been widely used by the marketers to tap human senses and guide them to choose brands in multi-branded product outlets. The service industry has also adopted subliminal sensory-based branding, namely, Singapore Airlines, for example, masks fragrance with interior colour and hue of the cabin and reflects the image in the uniforms of flight attendants (sight) to create a unique sensory experience for their customers. Joshua (2008) and Morrin and Chebat (2005), in one of their studies, found significant relationship between the use of aroma and increase in sales in multi-branded retails. The tourism industry has also initiated tapping human senses, namely, olfactory (aroma), optic (visuals), tactile (touch), gustative (taste) and auditory (hearing) to allow a multi-sensory image perception of brands. Sensory inputs in the context of destination attributes and tourism products contribute in perceived destination image. Multisensory branding techniques can be used for differentiating destinations based on sensory image perception (Fan, 2006).

This study argues that sensory and attributional image of a destination, apart from the perceived cognitive and affective image, are critical brand associations to influence the perceived image of destination. The destination brand model has been posited on this assumption of multiple inputs in creating perceived destination image. The study further implicates the impact of perceived brand image on the post-travel behavioural pattern of visitors. Although sensory and attributional images are assumed to shape destination branding, empirical studies to assimilate their effects in conjunction with the cognitive and affective image inputs have remained inconclusive.

\section{Literature review}

The strategy of branding destinations has been used as differentiator between multiple destinations based on attributes specific to the destination (Morrison \& Anderson, 2002). Considering the complexity involved in branding a destination based on attributes and perceived image it is quite inevitable that creation of a branded identity is equally important as differentiation ( $\mathrm{Qu}$ et al., 2011). The visitors develop an attachment with the destination based on the projected brand identity developed from travel experience (Konecnik \& Go, 2008). Apart from creating a brand identity, a branded destination differentiates itself from its competing destinations in terms of unique attributes, scope-of-activities and image that serve as an attachment factor for the visitors namely accommodation facilities, dining facilities, public utilities, accessibility, socio-emotional attractions, ethno-cultural phenomenon and physical landscape (Baker, 
2007). Point of differentiation facilitate visitors to perceive destinations image based on the identity created (Keller, 2008). Many studies, thus far, have posited that brand image and brand identity are critical in the formation of a destination brand (Florek et al., 2006; Nandan, 2005) with the brand image aggregating perceptions of visitors about a brand as projected by the brand associations (Keller, 2008) and brand identity, on the other hand, incorporates brand elements, assigns direction to the strategic brand vision and synthesizes brand associations (Keller, 1998; Aaker, 1996). While branding a destination the marketer propagates the brand identity, based on destination attributes, as a potent differentiator to stimulate visitors' perception of the destination image (Florek et al., 2006). Destination marketers can create a positive brand image of the destination by emphasizing on unique brand associations (Qu et al., 2011).

Brand associations stimulate consumer decision about brand preference (Low \& Lamb, 2000) and has been classified into attributes, benefits and attitudes (Keller, 1998). While attributes are perceived to be the brand offerings, the benefits are the socio-emotional and experiential attachment with the brand based on the offerings ( $\mathrm{Qu}$ et al., 2011) and attitudes are reflective of the decisions based on evocation, an assimilation and synthesis of attributes and benefits. Brand attitudes inherently refers to the perceived image of the brand and are significant determinants of post-purchase behaviours. This notion received concurrence in the study by Ryan and Gu (2008) as they observed that perceived destination image as a critical brand asset is deterministic of post-travel behavioural pattern of the visitors. Past studies have identified cognitive and affective inputs towards the formation of destination image (Hosany et al., 2007). Cognitive inputs are beliefs and logical synthesis associated with the destination visited and affective evaluation refers to the feelings associated with the same (Baloglu \& Brinberg, 1997). The Image Formation Process (IFP) laid down by Gartner (1993) considered as a comprehensive model for destination branding is compatible with Keller's (1998) concept of brand associations. Cognitive and affective images were referred to as the 'push' factors (Pikkemaat, 2004) in perceiving a destination while the destination attributes were considered as the 'pull' factors (Lam \& Hsu, 2006; Nicolau \& Mas, 2004). Nolan and Keller-III (2006) identified three sets of destination attributes namely natural resources, cultural resources and commercial resources. Destination attributes were found to be significant influencers towards selection of a destination (Lam \& Hsu, 2006) and are apprehended to be critical in destination branding. This paper, therefore, proposes that the perceived destination brand image is influenced by the cognitive, affective and attributional image perceived by the visitors about the destination and draws rationale from the existing literature on destination image and brand associations. The attributional, cognitive, and affective image inputs are expected to have individual impact in the formation of perceived destination brand image unlike the previous notion of combined impact (Cai, 2002; Woodside \& Lysonski, 1989). Therefore the following hypotheses were proposed:

\section{H1: Cognitive image influences perceived destination brand image. \\ H2: Affective image influences perceived destination brand image. \\ H3: Attributional image influences perceived destination brand image.}

The influence of sensory perceptions on perceived brand image component has not been explored empirically for destinations, although, it is expected to be quite critical in shaping the overall perceived destination image. The use of multi-sensory branding strategy is replacing the conventional form of twodimensional marketing (use of sight $\&$ sound) with the five-dimensional model (use of all five human senses) to stimulate perception of a comprehensive brand image. The use of sensory perception can generate a humanized and anthropomorphic perception of destination image. Multi-sensory branding (based on sensory image perception) creates socio-emotional make-over of the visitors by linking the experiential output with the sensory organs creating a favourable memory-trap about the destination (Pawaskar \& Goel, 2014).Visual and olfactory senses were well used in the multi-branded retail industry to stimulate the subliminal perception of the consumers and assist them in purchase decisions (Baksi, 2013). Odours or aroma probe the human brain for impulse decision and often differentiates between propositions (Russell \& Pratt, 2008). The visual ambience of the destination makes a lasting imprint on the sensory perception of the visitors. Aroma of rustic soil, fragrance of wild flowers and smell of unpolluted terrain has 
served as travel motives (Baksi, 2016, 2017). Characterization of brands by signature tunes prevails in traditional format of marketing communication (Hulten, 2009) which often arouses evocation of exclusivity (Lindstrom \& Kotler, 2005). Destinations with indigenous ethno-cultural implications often use sound to lure visitors as witnessed in the tribe-infested destinations like Jangalmahal and Santiniketan in West Bengal. The sound of the Santhal (a tribe) drum and flute has profound cognitive impact in the subconscious of the visitors to the extent of predisposing travel motive for repeat visitation and associate preference to the sound-of-destination. The sensorial strategy of taste, too, is probably one of the critical success factors to destination branding. Gustative branding or use of taste connects the visitors with the local gastronomy and can contribute to perceive destination image (Bertil et al., 2009). Tactile branding or use of touch has remained an elusive phenomenon in the consumer-product industry, but, in travel and tourism domain the human touch creates a sense of assurance for the visitors (Pawaskar \& Goel, 2014). The concept of tactile branding was also found in the practice of Craftourism (Baksi, 2016, 2017) as visitors experience hands-on activity in moulding local crafts. Rewatkar (2009) observed that creation of brand consciousness depends on socio-emotional linkages triggered by the activation of five human senses. Qu et al. (2011) introduced the concept of 'unique image', a comprehensive differentiator that envisages the overall destination brand image. Sensory images, at the micro level, can be a more potent contributor to destination image building as it aggregates destination attributes and scope-of-activities to facilitate associations (Keller, 2008).

Therefore it is deduced that:

H4: Sensory image will affect perceived destination brand image.

$\mathrm{Yu}$ and Dean (2001) observed that perceptual evaluation of destination brand image acts as an antecedent to socio-emotional state (e.g. satisfaction) leading to post-travel behaviours. Kuenzel and Katsaris (2009) observed two significant post-travel behaviours of visitors namely intention to return or repeat visitation and advocacy through word-of-mouth (WOM). This study was a reinforcement to the findings by Murray (1991) and Alcaniz et al. (2005). Bigné et al. (2001), too, found that perceived destination image impacts a number of post-travel behaviours including destination choice option for future travel plans. WOM can serve as a positive indicator of perceived destination brand image (Yvette \& Turner, 2002; Weaver \& Lawton, 2002; Oppermann, 2000). Therefore it is hypothesized that:

H5: Perceived destination brand image influences intention to revisit by visitors.

H6: Perceived destination brand image influences positive advocacy \& WOM by visitors.

Traditional format of mass branding, however, is far from effective to cut the clutter, more so, for service brands typically mystified with intangibility and heterogeneity. Concept of 'relationship' is fast replacing the 'transactional exchange'-based marketing notions (Fournier, 2012). Relationship marketing is posited on the realm of interpersonal exchanges namely reciprocity, purposiveness, broad-spectrum coverage and process phenomena (Hinde, 1995). Researchers have explained 'relationship' in the context of branding by proposing the concept of 'brand-as-partner' (Fournier, 1998) whereby brands are humanized, personalized and animated. Thus far, relationship, as a multiplex phenomenon have been studied as socioemotional state culminating into psycho-social identity-complex, namely, perceiving images and social integration (Fehr \& Russell, 1991). Most of the researchers have used a five-phase model of relationship covering initiation, growth, maintenance, deterioration and dissolution (Levinger, 1983). Past research identified broad socio-demographical and ethno-cultural aspects to define relationship attitudes and behaviours (Dion \& Dion 1996; Levinger 1995). These factors were found to influence the strength of relationship drives, the types of relationships cherished and desired, the pattern of emotional expression in relationships, pattern of interaction in relationships, the manner in which relationships are dissolved and the degree to which sustainable commitments are sought (Holt, 1997; Thompson, 1996). Considering the strength of 'relationship' paradigm to mould behavioural issues and the scope of its embodiment in branding, the researcher expects a significant and positive moderating effect of relationship-branding on 
the relationship between perceived destination brand image and post-travel behavioural pattern of visitors. Therefore it is hypothesized that

H7: The impact of perceived destination brand image on post-travel behaviours of the visitors is significantly increased under the impact of relationship-branding efforts

Fig. 1 represents the conceptual model involving all the variables:

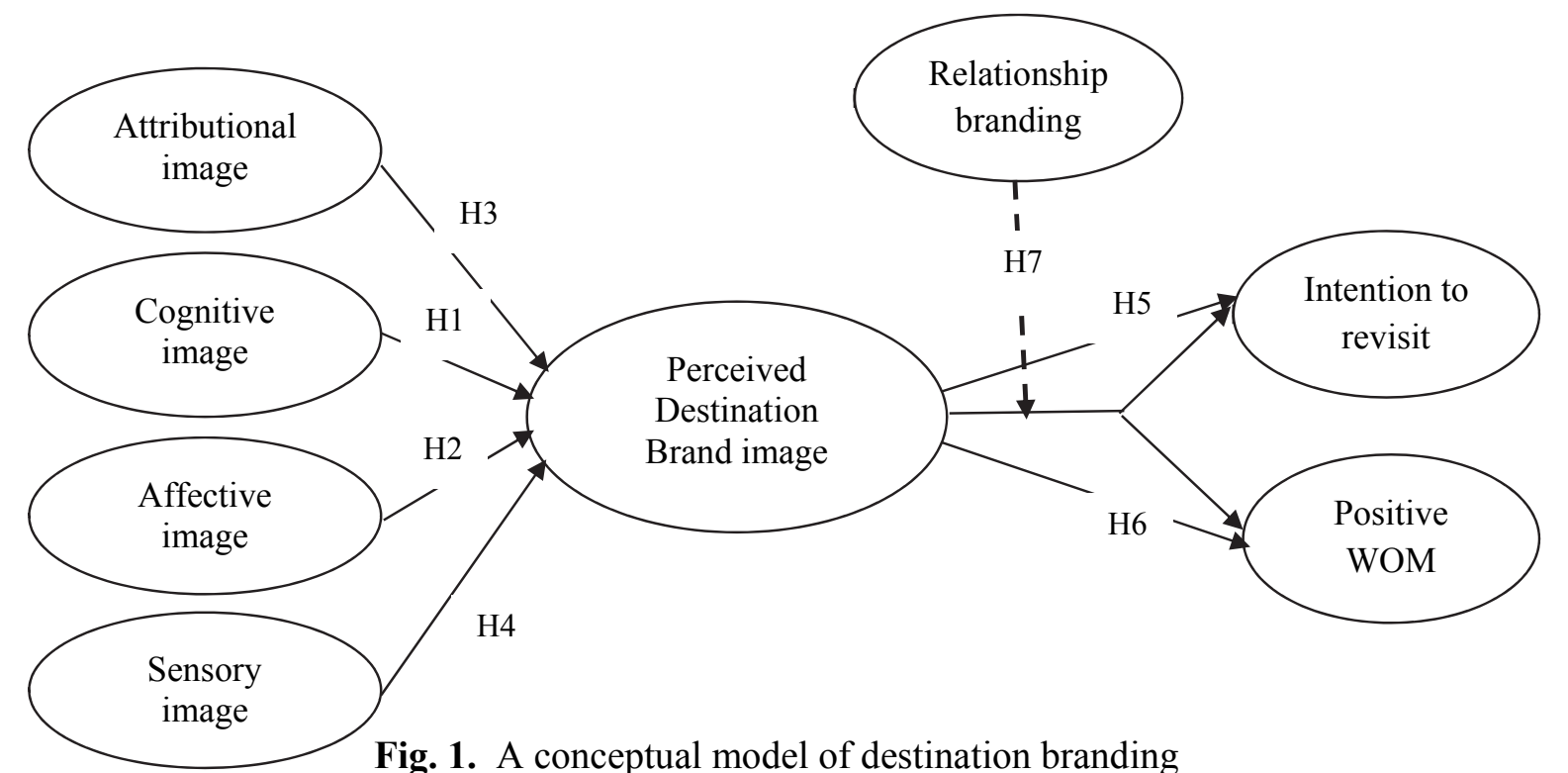

\section{Methodology}

Three districts of West Bengal, India, namely, Birbhum, Murshidabad and Bankura were selected for the study by considering their attraction based on ethno-cultural heritage and traditional art \& craft forms. Three specific destinations namely Santiniketan (Birbhum), Bishnupur (Bankura) and Murshidabad were chosen known to induce profound influx of both domestic and foreign visitors. Considering the experiential nature of the study, extreme mobility of the respondents (visitors) and unknown variability of the population, the study used confidence interval approach (Burns \& Bush, 1995) to determine the sample size. The sample size was determined at the level of $95 \%$ accuracy with $95 \%$ confidence interval:

$$
n=\frac{z^{2} p q}{e^{2}}=\frac{1.96^{2}(0.4 \times 0.6)}{0.05^{2}}=370
$$

whereby, $\mathrm{n}=$ sample size,

$\mathrm{p}=$ estimated variability in the population $40 \% *$

$\mathrm{q}=(1-\mathrm{p})$

$\mathrm{z}=$ standard error associated with chosen level of confidence $(95 \%)$

$\mathrm{e}=$ acceptable error $+5 \%($ desired accuracy $95 \%)$

The response rate and un-usability of response were assumed to be $60 \%$ and $10 \%$, respectively. Therefore $529(370 / 0.70)$ visitors (respondents) were approached for the study. For the hoteliers and other service providers stratified random sampling was used. From the enlisted hotels and resorts, restaurants, logistic service providers and tour-guides obtained from the local administration a random number between 1 and 10 was chosen to decide on the first sample unit and the successive unit or the interval size (k) was calculated as $\mathrm{k}=\mathrm{N} / \mathrm{n}$ (population size/ sample size). A total number of 18 hotels $\&$ resorts, 9 restaurants, 9 logistic service providers and 12 tour-guides were interviewed. A structured questionnaire was used for the study purpose. The survey instrument was a structured questionnaire. 
Perceived cognitive image was measured with a list of 43 items adopted from the study of Qu et al. (2011). Perceived affective image was measured with the bi-polar scale developed by Russel et al. (1981). The four dichotomous distribution of the scale $(0 \& 1)$ included: arousing-sleepy, pleasant-unpleasant, exciting-gloomy and relaxing-distressing. The items capturing the perceived sensory image of the visitors were adopted from the studies made by Russel (1981), Pawaskar and Goel (2014), Rewatkar (2014) and Bertil et al. (2009). Attributional image perception was measured with 42 items aggregated from the studies of Joppe et al (2001) and Opperman (1996). A 7 point Likert scale was assigned to generate and interpret response. The questions regarding post purchase behaviour of the visitors namely intention to revisit and positive WOM were fitted in a 5 point scale with ' 1 'being most unlikely and ' 5 'being most likely. The relationship construct was adopted from the studies of Fournier (1998) and was measured with 15 items. The perceived destination-brand image was measured using 12 items taken from the study of Echtner and Ritchie (2003). Pilot study was conducted to understand the capability of the instrument to capture the constructs adequately.

A reliability test was conducted which measured the Cronbach's alpha for perceived images namely cognitive (0.89), sensory (0.91) and attributional (0.93) which were considered acceptable as standard reliability measure (Hair et al., 1998). The Cronbach's alpha for relationship-branding was found to be 0.85 .

\subsection{Data analysis}

Exploratory factor analysis (EFA) was used to determine the factor structure of perceived destination brand image with inputs from cognitive, sensory and attributional image constructs. The determinant of the correlation matrix was found to be .007 which established that it is neither an identity matrix nor a singularity matrix and hence provided substantial evidence of interrelationship between the items under study. The Barlett's test of Sphericity gave significant result $\left(\chi^{2}=1972.41, p=0.00\right)$, thereby, confirming that the correlation matrix is not an identity matrix. The KMO result (0.879) established sample adequacy (Hair et al., 1998) and hence the data was found amenable to EFA. Based on the eigen value criteria (eigen value $>1$ ) a four factor solution was retained for perceived destination brand image. These four factors account for 24.090 (attributional image), 17.181 (cognitive image), 15.912 (sensory image) and 14.011 (affective image) \% of the total variance, respectively and together accounted for $71.19 \%$ of the total variance. Relationship branding was explained adequately by five factors, namely intimacy, commitment, self-connection, interdependence and brand-partner quality which attributed for $74.65 \%$ of variance. The principal component analysis using orthogonal rotation (VARIMAX with Kaiser normalization) allowed to identify the underlying factor structures of perceived image inputs. Factors with low loading scores $(<0.60)$ were deleted (Hair et al., 1998). The results of the EFA using PCA are summarized in Table 1.

Regression analysis used to test whether there is a direct effect of input images namely attributional (ATTR), cognitive (COGN), sensory (SENS) and affective (AAFCT) on perceived destination brand image (H1, H2, H3 and H4). The regression model stands as:

$Y_{t}=\beta_{1}+\beta_{2} X_{t}+\beta_{3} X_{t}+\beta_{4} X_{t}+\beta_{5} X_{t}+u_{t}$

whereby, Yt is the value of the dependent variable (perceived destination brand image) on time period $\mathrm{t}$, $\mathrm{X}$ are the values of independent variables on time period t. $\beta_{1}$ is the intercept or average value of dependent variable when all the independent variables are absent. $\beta_{2}, \beta_{3}, \beta_{4}$ and $\beta_{5}$ are the slope of perceived destination brand image (partial regression coefficients) with respect to the independent variables. $u_{t}$ is the random error in $\mathrm{Y}$ for time period t. Hence the model as:

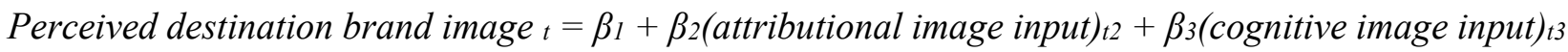
$+\beta_{4}(\text { sensory image input })_{t 4}+\beta_{5}(\text { affective image input })_{t 5}+u_{t}$ 


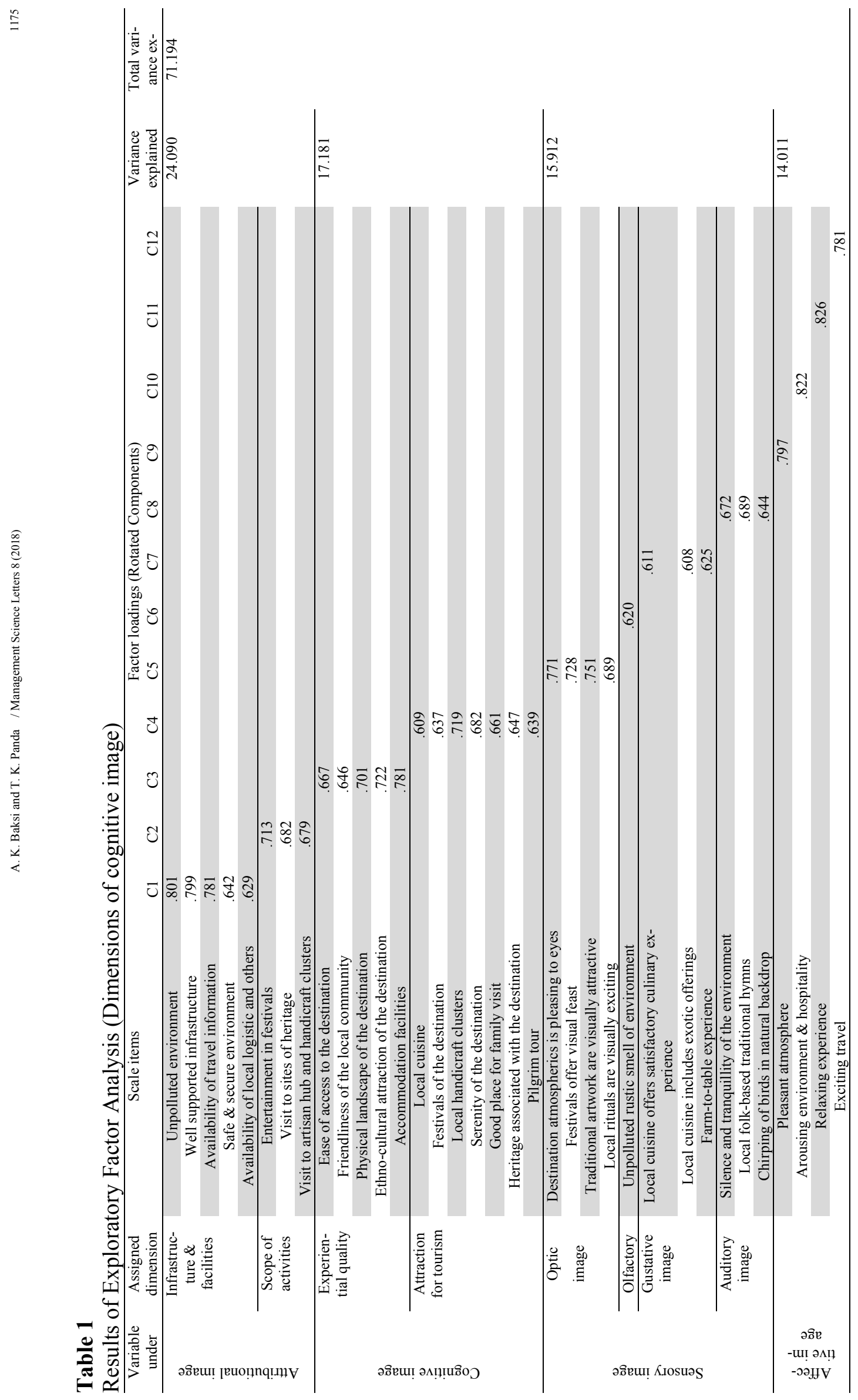


The measurement models for the variables can be represented as in Table 2 .

Table 2

Measurement model

\begin{tabular}{lcc}
\hline \multicolumn{1}{c}{ Major variables } & Dimensions assigned & Total variance explained \\
\hline \multirow{2}{*}{ Attributional image } & Infrastructure \& facilities & $71.19 \%$ \\
\hline \multirow{2}{*}{ Cognitive image } & Scope of activities \\
\hline \multirow{2}{*}{ Sensory image } & Experiential quality \\
& Attraction for tourism \\
\hline \multirow{2}{*}{ Affective } & Optic image \\
& Olfactory image \\
& Gustative image \\
\hline & Auditory image \\
\hline Arousing environment \& hospitality \\
Relationship branding & Exciting travel \\
& Intimacy \\
& Self-connection \\
\hline
\end{tabular}

The results of regression analyses were summarized in Table 3, Table 4 and Table 5. The model summary (Table 1) displayed $\mathrm{R}^{2}$ to be as .543 indicating that the image (attributional, cognitive, sensory and affective) inputs accounted for $54.3 \%$ of the variation in aggregate in perceived destination brand image which is significant enough for the predictability of the model. The results of ANOVA (Table 2) confirmed that the variation showed by the independent variables was significant at $1 \%$ level $(\mathrm{F}=39.086$, $\mathrm{p}<.001$ ). Regression coefficients (Table 5) confirmed a significant and strong associationship between ATTR and PDBI $(\beta=.669, \mathrm{t}=8.728, \mathrm{p}<.001), \mathrm{COGN}$ and PDBI $(\beta=.473, \mathrm{t}=6.534, \mathrm{p}<.001)$ and SENS and PDBI $(\beta=.536, t=7.760, p<.001)$. Moderately strong associationship was observed between AFFCT and PDBI $(\beta=.218, \mathrm{t}=3.775, \mathrm{p}<.005)$. Therefore the predictive capability of the model was established. Table3, Table-4 and Table 5 supported H1, H2, H3 and H4.

Table 3

Regression analysis: Model summary

\begin{tabular}{ccccccccccc}
\hline Model & $\mathrm{R}$ & R Square & $\begin{array}{c}\text { Adjusted R } \\
\text { Square }\end{array}$ & $\begin{array}{c}\text { Std. Error of } \\
\text { the Estimate }\end{array}$ & $\begin{array}{c}\text { R Square } \\
\text { Change }\end{array}$ & F Change & df1 & Change Statistics & $\begin{array}{c}\text { Sig. F } \\
\text { df2 }\end{array}$ \\
\hline 1 & $.737^{\mathrm{a}}$ & .543 & .039 & .41214 & .543 & 39.086 & 4 & 1886 & .000 \\
\hline
\end{tabular}

a. Predictors: (Constant), AFFCT, SENS, ATTR, COGN

b. Dependent Variable: PDBI

Table 4

Regression analysis: ANOVA

\begin{tabular}{ccccccc}
\hline & Model & Sum of Squares & df & Mean Square & F & Sig. \\
\hline \multirow{3}{*}{1} & Regression & 6.173 & 4 & 1.543 & 39.086 & $.000^{\mathrm{b}}$ \\
\cline { 2 - 8 } & Residual & 320.353 & 1886 & .170 & & \\
\hline
\end{tabular}

\footnotetext{
a. Dependent Variable: PDBI

b. Predictors: (Constant), AFFCT, SENS, ATTR, COGN
} 
Table 5

Regression analysis: Coefficients

\begin{tabular}{|c|c|c|c|c|c|c|c|c|}
\hline & \multirow[t]{2}{*}{ Model } & \multicolumn{2}{|c|}{$\begin{array}{c}\text { Unstandardized } \\
\text { Coefficients }\end{array}$} & \multirow{2}{*}{$\begin{array}{c}\begin{array}{c}\text { Standardized } \\
\text { Coefficients }\end{array} \\
\text { Beta } \\
\end{array}$} & \multirow[t]{2}{*}{$\mathrm{t}$} & \multirow[t]{2}{*}{ Sig. } & \multicolumn{2}{|c|}{ Collinearity Statistics } \\
\hline & & $\mathrm{B}$ & Std. Error & & & & Tolerance & VIF \\
\hline \multirow{5}{*}{1} & (Constant) & 34.793 & 12.034 & & 141.983 & .000 & & \\
\hline & ATTR & 18.015 & 5.009 & .669 & 8.728 & .000 & .329 & 3.039 \\
\hline & COGN & 12.015 & 4.010 & .473 & 6.534 & .000 & .227 & 4.407 \\
\hline & SENS & 23.024 & 6.009 & .536 & 7.760 & .000 & .213 & 4.701 \\
\hline & AFFCT & 9.017 & 2.022 & .218 & 3.775 & .001 & .997 & 1.003 \\
\hline
\end{tabular}

a. Dependent Variable: PDBI

Regression analysis was also used to test the impact of perceived destination brand image (PBDI) on intention to revisit (INREV) (H5) and positive word-of-mouth (PWOM) (H6). The results of regression analyses were summarized in Table 6 and Table 7. The model summary (Table 6 and Table 7) displayed $\mathrm{R}^{2}$ to be as .565 and .670 respectively indicating that INREV and PWOM can explain $56.5 \%$ and $67.0 \%$ of variation in PBDI which is significant enough for the predictability of the model. The results of ANOVA (Table 6 and Table 7) confirmed that the variation showed by the independent variables was significant at $1 \%$ level e.g. $\mathrm{F}=43.983, \mathrm{p}<.001$ for INREV and $\mathrm{F}=52.115, \mathrm{p}<.001$ for PWOM respectively. Regression coefficients (Table- 6 \& Table-7) confirmed a significant and strong associationship between PDBI and INREV $(\beta=.712, \mathrm{t}=12.287, \mathrm{p}<.001)$ and PDBI and PWOM $(\beta=.589, \mathrm{t}=10.912, \mathrm{p}<.001)$ Therefore the predictive capability of the model was established.

Table 6

Regression summary

\begin{tabular}{cccccccc}
\hline & Model summary & & \multicolumn{2}{c}{ ANOVA } & \multicolumn{3}{c}{ Coefficients } \\
\hline Model & $\mathrm{R}$ & R square & F & Sig & Beta & T & Sig. \\
\hline 1 & .752 & .565 & 43.983 & .000 & .712 & 12.287 & .000 \\
\hline Dependent variable: INREV & & & & &
\end{tabular}

Predictor: PDBI

Table 7

Regression summary

\begin{tabular}{cccccccc}
\hline & Model summary & & \multicolumn{2}{c}{ ANOVA } & \multicolumn{3}{c}{ Coefficients } \\
\hline Model & $\mathrm{R}$ & $\mathrm{R}$ square & $\mathrm{F}$ & $\mathrm{Sig}$ & Beta & $\mathrm{T}$ & Sig. \\
\hline 1 & .819 & .670 & 52.115 & .000 & .589 & 10.912 & .000 \\
\hline
\end{tabular}

Dependent variable: PWOM

Predictor: PDBI

To test the moderating effect of RELBRND on the relationship between PDBI and post-travel behaviour, bootstrapping procedure (Preacher \& Hayes 2008) was used. Bootstrapping was used to compute a confidence interval (CI) around the indirect effect. A bootstrap CI that does not include zero provides evidence of a significant indirect effect of PBDI on post-travel behaviours (INREV \& PWOM) through RELBRND. The moderation analysis was performed by applying Hayes' PROCESS SPSS macro, using 5.000bootstrapped samples to estimate the indirect effect. The researcher used the estimation of conditional indirect effects and tested whether these indirect effects differ from zero at specific value of the moderator (e.g. relationship branding efforts) using a bootstrap Confidence Interval (CI) as recommended 
by Preacher et al. (2007). As predicted, the results (Table 8) showed a significant moderating effect of RELBRND on post-travel behaviours and was found to be consistently positive and increased with the level of RELBRND. The effect was significantly different from zero among those who have low $(95 \%$ $\mathrm{CI}=0.0652$ to 0.1983$)$, moderate $(95 \% \mathrm{CI}=0.1265$ to 0.2439$)$, and high levels $(95 \% \mathrm{CI}=0.2093$ to 0.4012) of impact from RELBRND. Thus, H7 was supported.

Table 8

Conditional effects of the focal predictor on dependent variable at values of the moderator

\begin{tabular}{cccccccc}
\hline RELBRND & Effect $(\beta)$ & $\mathrm{se}$ & $\mathrm{t}$ & $\mathrm{p}$ & LLCI & ULCI & $\begin{array}{c}\text { 95\% Bias corrected } \\
\text { bootstrap CI }\end{array}$ \\
\hline Low: -1.3427 & .23 & .35 & 7.53 & .000 & .07 & .20 & 0.0652 to 0.1983 \\
Moderate: 0.000 & .19 & .21 & 6.00 & .001 & .14 & .27 & 0.1265 to 0.2439 \\
High: 1.3986 & .33 & .44 & 8.90 & .000 & .36 & .41 & 0.2093 to 0.4012 \\
\hline
\end{tabular}

Focal predictor: PBDI $(\mathrm{X})$

Moderating variable: RELBRND (M)

Dependent variable: Post-travel behaviour (Y)

The measurement model was estimated to assess the overall model fit. The fit statistics obtained through confirmatory factor analysis (CFA) assured a good fit for the model $\left(\chi^{2}=3245.54, \mathrm{df}=368, \mathrm{p}<0.01\right.$, GFI $=.97, \mathrm{AGFI}=.95, \mathrm{TLI}=.91)$. Indicator loadings for statistical significance were obtained. Estimation of reliability and variance extracted were also performed. The results of the loadings with $t$ values are shown in Table 9. As far as reliability of the image constructs are concerned, attributional image (.88), cognitive image (0.81), sensory image (0.78) and affective image (0.74) surpassed the threshold level of 0.70 ( $\mathrm{Qu}$ et al, 2011). The measures support the convergent validity of the items. For variance extraction, all the three constructs namely attributional image (.77), cognitive image (0.72), sensory image (0.66) and affective image (0.59) met the cut-off value of 0.50 .

Table 9

SEM results: Standardized parameter estimates for SEM model construct loadings

\begin{tabular}{|c|c|c|c|c|c|c|c|c|}
\hline \multirow[b]{2}{*}{$\begin{array}{l}\text { Endogenous } \\
\text { constructs }\end{array}$} & \multirow[b]{2}{*}{ RELBRND } & \multirow[b]{2}{*}{ INREV } & \multirow[b]{2}{*}{ PWOM } & \multicolumn{4}{|c|}{ Exogenous constructs } & \multirow[b]{2}{*}{$\begin{array}{l}\text { Structural } \\
\text { equation fi } \\
\left(\mathrm{R}^{2}\right) / \mathrm{VE}\end{array}$} \\
\hline & & & & $\begin{array}{l}\text { Attribu- } \\
\text { tional im- } \\
\text { age }\end{array}$ & $\begin{array}{l}\text { Cognitive } \\
\text { dimension }\end{array}$ & $\begin{array}{l}\text { Sensory di- } \\
\text { mension }\end{array}$ & $\begin{array}{l}\text { Affective } \\
\text { dimension }\end{array}$ & \\
\hline RELBRND & 0.000 & 0.000 & 0.000 & $\begin{array}{c}0.88 \\
\left(6.82^{* *}\right)\end{array}$ & $\begin{array}{c}0.81 \\
\left(5.72^{* *}\right)\end{array}$ & $\begin{array}{c}0.78 \\
\left(4.94^{* *}\right)\end{array}$ & $\begin{array}{c}0.74 \\
\left(3.08^{*}\right)\end{array}$ & 0.61 \\
\hline INREV & $0.64\left(4.81^{* *}\right)$ & 0.000 & 0.000 & 0.000 & 0.000 & 0.000 & 0.000 & 0.56 \\
\hline PWOM & $0.56\left(3.97^{*}\right)$ & 0.000 & 0.000 & 0.000 & 0.000 & 0.000 & 0.000 & 0.39 \\
\hline $\begin{array}{l}\text { Variance } \\
\text { extracted }\end{array}$ & & & & 0.77 & 0.72 & 0.66 & 0.59 & \\
\hline Chi-square & \multicolumn{8}{|c|}{3245.54} \\
\hline Df & \multicolumn{8}{|c|}{368} \\
\hline Sig & \multicolumn{8}{|c|}{.000} \\
\hline GFI & \multicolumn{8}{|c|}{.97} \\
\hline AGFI & \multicolumn{8}{|c|}{.95} \\
\hline TLI & \multicolumn{8}{|c|}{.91} \\
\hline RMSEA & \multirow{2}{*}{\multicolumn{8}{|c|}{.04}} \\
\hline RMSR & & & & \multicolumn{5}{|c|}{0.069} \\
\hline
\end{tabular}

*Significant at 0.05 level (critical value $=1.96)$

** Significant at 0.01 level (critical value $=2.576$ )

The structural model was accepted based on the results of CFA (Table-9) as the goodness-of-fit indices supported the cause. All the paths in the structural model were statistically significant.

\section{Conclusion and implication}

The study was designed to construct a model of destination branding based on perceived destination brand image and used the existing theory to measure destination brand image incorporating contributions of cognitive and affective inputs. The study hypothesized two more dimensions to have profound signif- 
icant effect on perceived destination brand image namely destination attributions and sensory perceptions. Use of multisensory perceptions were well discussed in the context of service environments namely retail environment. The results confirmed that the destination brand model on the premise of perceived destination brand image could be adequately accounted for by the four dimensions apprehended to have antecedent impact. The study confirmed earlier studies (in retail sectors) by Russel (1981) regarding the impact of sensory perception of visitors towards framing a brand image. Although the inherent criticality of service industry with regard to its intangibility and lack of standardization (heterogeneity) inhibits the usage of sensory perception to a lesser extent compared to a more tangible product market; sensory image input, apart from the tactile image, was found to have a prominent role to play in the destination brandimage. Sensory image should not be confused with the cognitive image. Sensory image imparts a physical assimilation of feelings as opposed to psychological interpretations made by the cognitive self. Examinations are required with regard to the contribution of sensory perception in capturing the unique image of a destination. Cognitive and affective images were found to have significant impact on the overall perceived destination brand image which reinforced the earlier studies made by Baloglu and McCleary, (1999), Stern and Krakover (1993).

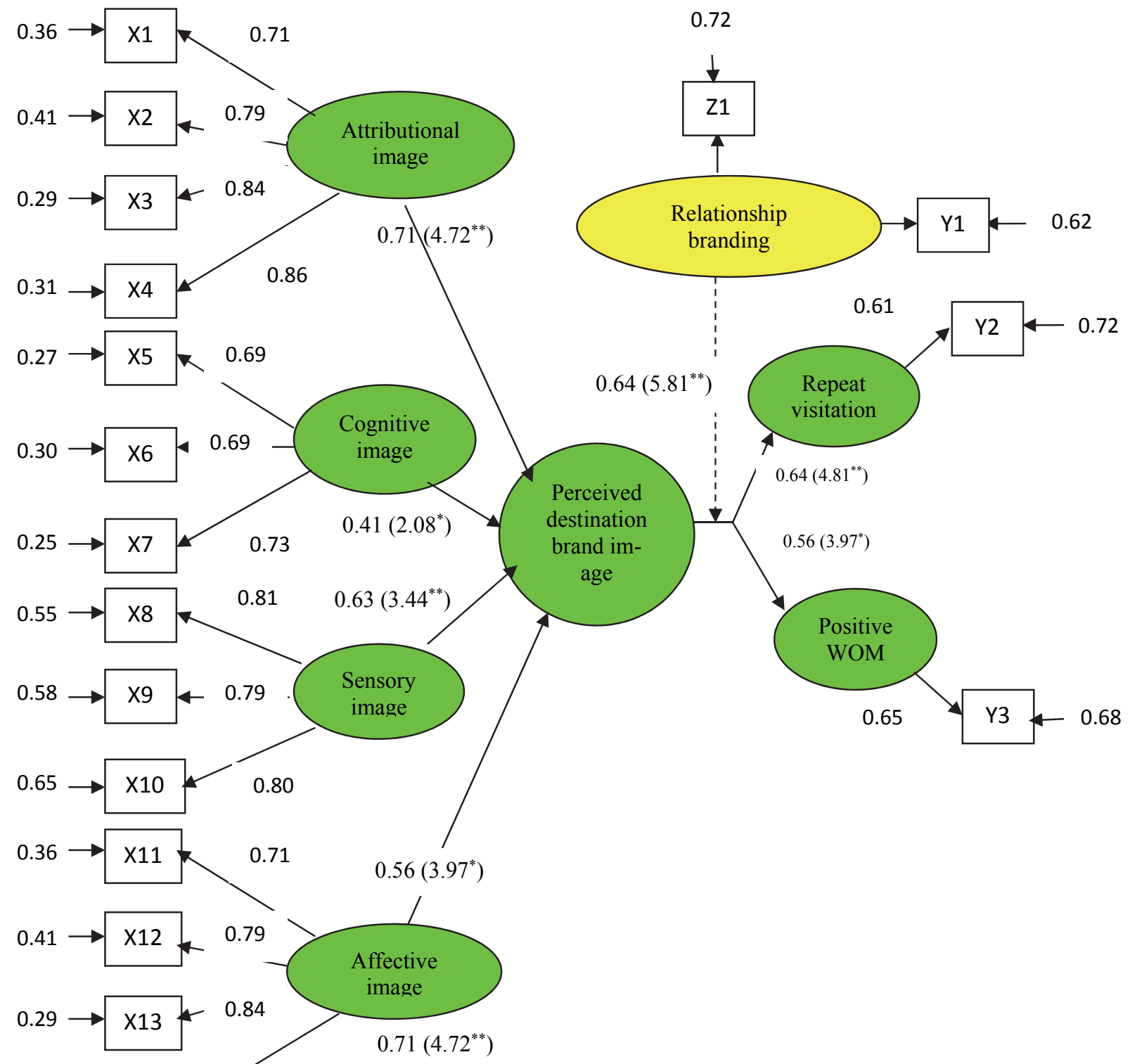

$0.31 \rightarrow \mathrm{x} 14 \quad 0.86 \quad$ Fig.2. Final structural model 
The study confirmed a significant impact of affective brand associations in projecting destination brand image and thereby supported the notion of Baloglu and McCleary's (1997) observations. The perceived destination brand image was tested for its predictive impact on post-travel behaviours and was found to have significant influence on visitors' intention to revisit and advocating positive word-of-mouth. The results confirmed the previous observations that perceived brand image of a destination influences the probability of repeat visitation and positive WOM on the part of the visitors (Alcaniz et al., 2005). It was also noted that destination brand image as a holistic variable had a more deterministic role in post-travel behaviours compared to the individual brand association components and as a result supported the earlier notion of Baloglu and Brinberg (1997) that the brand association components are often converged. Concept of relationship branding was developed for the study taking cues from the observations of Fournier (2010) and other researchers propagating the concept of 'brand-as-partners', 'humanized brands' and 'anthropomorphism' and was tested for its intervening (moderating) effect on the relationship between perceived destination brand image and post-travel behaviours. Bootstrapping, using confidence interval measures, confirmed that the impact of perceived destination brand image increases on positive posttravel behaviours if the 'destination-brand' is relation-driven or act as biotic partners rather than emotionless inanimate objects. The study also confirmed the interpretations of Qu et al. (2011) about the role of brand-as-partners in creating the overall perceived destination brand which must be congrual with the destination brand identity in order to have a significant impact on the post-travel behaviours. The present study identified a number of differentiating factors to brand destinations on uniqueness, specifically, on the ground of multisensory image inputs namely visual image related to local festivals, culture and tradition, gustative image namely farm-to-table cuisine and auditory image namely local folklores and hymns. Destination marketers may incorporate these sensory inputs to facilitate a positive destination brand image. The study has been restricted to specific destinations and, therefore, needs to be expanded in other geo-demographical destinations for generalization. In future other staying options should be explored to incorporate probable different layers of visitors. Destination brand image may be influenced by other variables namely travel motives and therefore travel motives should be explored as a brand association component.

\section{References}

Aaker, D. A. (1996). Building strong brands, New York: The Free Press.

Alcaniz, E. B., Garcia, I. S., \& Blas, S. S. (2005). Relationships among residents' image, evaluation of the stay and post-purchase behavior. Journal of Vacation Marketing, 11(4), 291-302

Baker, B. (2007). Destination branding for small cities: The essentials for successful place branding. Portland: Creative Leap Books

Baksi, A. K. (2016). Impact of Craftourism on place attachment: A case of selected craft districts in West Bengal India. South Asian Journal of Tourism and Heritage, 9(2), 27-39.

Baksi, A. K. (2017). Linking consumer trust, repatronization and advocacy with intervention of perceived service recovery and zone-of-tolerance. Asian Journal of Management, 8(2), 324-330.

Baksi, A. K. (2013). Moderating effects of CRM on e-tail atmospherics-shopping behaviour link: A case of modified Mehrabian-Russell model, SIT Journal of Management (online), 3 (Spl.), 1-27.

Baloglu, S. \& Brinberg, D. (1997). Affective images of tourism destination. Journal of Travel Research, 35(4), 11-15

Baloglu, S. \&Mangaloglu, M. (2001). Tourism destination images of Turkey, Egypt, Greece, and Italy as perceived by US-based tour operators and travel agents. Tourism Management, 22(1), 1-9.

Baloglu, S. \& McCleary, K. (1999). A model of destination image formation. Annals of Tourism Research, 26(4), 868-897.

Bertil, H., Broweur, N. \& Van Dijk, M. (2009). Sensory Marketing. New York: Palgrave Macmillan.

Bigné, J. E., Sánchez, M. I. \& Sánchez, J. (2001). Tourism image, evaluation variables and after purchase behaviour: inter-relationship. Tourism Management, 22(6), 607-616.

Blain, C., Levy, S. E. \& Ritchie, J. R. B. (2005). Destination branding: insights and practices from destination management organizations. Journal of Travel Research, 43(4), 328e338. 
Bove-Sans, M. A., \& Laguado-Ramírez, R. (2013). Destination image analysis for Tarragona cultural heritage. Review of Economic Analysis, 5(1), 103-126.

Burns, A. C. \& Bush, R. F. (1995). Marketing research, New Jersey: Prentice Hall.

Cai, A. (2002). Cooperative branding for rural destinations. Annals of Tourism Research, 29(3), 720-742.

Chen, C. F., \& Phou, S. (2013). A closer look at destination: Image, personality, relationship and loyalty. Tourism management, 36, 269-278.

Dion, K. \& Dion, K. (1996). Cultural Perspectives on Romantic Love. Personal Relationships, 3 (March), 5 - 17.

Echtner, C. M., \& Ritchie, J. R. (2003). The meaning and measurement of destination image:[Reprint of original article published in v. 2, no. 2, 1991: 2-12.]. Journal of tourism studies, 14(1), 37.

Fan, Y. (2005). Branding the Nation: What is being branded. Journal of Vacation Marketing, 12, 1, 5-14.

Fehr, B. \& Russell, J. A. (1991). The concept of love viewed from a prototype perspective. Journal of Personality and Social Psychology, 60 (March), 425- 438.

Florek, M., Insch, A. \& Gnoth, J. (2006). City council websites as a means of place brand identity communication. Place Branding, 2(4), 276-296.

Fournier, S. \& Alvarez, C. (2012). Brands as relationship partners: Warmth, competence, and in-between. Journal of Consumer Psychology, 22, 177-185.

Fournier, S. (1998). Consumers and their brands: Developing relationship theory in consumer research. Journal of Consumer Research, 24(March), 343-373.

Gartner, W. C. (1993). Image formation process. Journal of Travel and Tourism Marketing, 2(2/3), 191-215.

Hair, J. F., Anderson, R. E., Tatham, R. L. \& Black, W. C. (1998). Multivariate data analysis (5th ed.). New Jersey: Prentice Hall.

Hinde, R. A. (1995). A Suggested Structure for a Science of Relationships. Personal Relationships, 2 (March), 115.

Hultén, B., Broweus, N., \& Van Dijk, M. (2009). What is Sensory Marketing?. In Sensory marketing (pp. 1-23). Palgrave Macmillan, London.

Holt, D. B. (1995). How Consumers Consume: A Typology of Consumption Practices. Journal of Consumer Research, 22 (June), 1- 16.

Hosany, S., Ekinci, Y. \& Uysal, M. (2007). Destination image and destination personality. International Journal of Culture, Tourism and Hospitality Research, 1(1), 62-81.

Joppe, M., Martin, D. W., \& Waalen, J. (2001). Toronto's image as a destination: a comparative importance-satisfaction analysis by origin of visitor. Journal of Travel Research, 39(3), 252-260.

Joshua, G. G. (2008). Multisensory Marketing and its Application in Tourism. [online] Available at http://www.scribd.com/doc/9296907/Multi-Sensory-Marketing-and-Its-Application-in-Tourism [Accessed $11 / 11 / 2016]$

Kapferer, J. (1997). Strategic brand management. Great Britain: Kogan Page.

Keller, K. L. (2008). Strategic brand management: Building, measuring, and managing brand equity (3rd ed.). New Jersey: Prentice Hall.

Keller, K. L. (1998). Strategic brand management: Building, measuring, and managing brand equity, New Jersey: Prentice Hall

Konecnik, M. \& Go, F. (2008). Tourism destination brand identity: the case of Slovenia. Brand Management, 15(3), 177-189.

Kuenzel, S. \& Katsaris, N. (2009). A Critical Analysis of Service Recovery processes in the Hotel Industry, TMC Academic Journal, 4(1), 14-24.

Lam, T. \& Hsu, C. (2006). Predicting behavioral intention of choosing a travel destination. Tourism Management, $27,589-599$.

Levinger, G. (1983). Development and Change, in Close Relationships, ed. Harold H. Kelley et al., New York: W. H. Freeman, 315-359.

Levinger, G. (1995) Figure versus Ground: Micro- and Macroperspectives on the Social Psychology of Personal Relationships in Theoretical Frameworks for Personal Relation-ships, ed. Ralph Erber and Robin Gilmour, Hillsdale, NJ: Erlbaum, 1-28.

Lindstrom, M. \& Kotler, P. (2005). Brand sense build powerful brands through touch, taste, smell, sight, and sound. New York: Free press

Low, G. S. \& Lamb, C. W. (2000). The measurement and dimensionality of brand associations. Journal of Product \& Brand Management, 9(6), 350-368.

Mariutti, F. G., Giraldi, J. D. M. E., \& Crescitelli, E. (2013). The image of Brazil as a tourism destination: an exploratory study of the American market. International Journal of Business Administration, 4(1), 13. 
Morrin, M. \& Chebat, J-C. (2005). Person-Place Congruency: The Interactive Effects of Shopper Style and Atmospherics on Consumer Expenditures. Journal of Service Research, 8(2), 181-191.

Morrison, A., \& Anderson, D. (2002). Destination branding. Available from: http:// www.macvb.org/intranet/presentation/DestinationBrandingLOzarks6-10-02. ppt, accessed on 11.11.16.

Murray, K. B. (1991). A test of services marketing theory: consumer information acquisition Activities. Journal of Marketing, 55(1), 10-25.

Nandan, S. (2005). An exploration of the brand identity-brand image linkage: a communications perspective. Brand Management, 12(4), 264-278.

Nicolau, J. L. \& Mas, F. J. (2004), Stochastic Choice Analysis of Tourism Destinations, Valenciano de Investigaciones Económicas, 2004, 1-34.

Nolan, M., J. \& Keller-III, F. C. (2006), Campfires, Cathedrals, and Casinos: Sociodemographic Variation and Perceptions of Tourist Destinations. Paper presented at the 2nd Annual Meetings of the Society for Anthropological Sciences, Savannah, GA, and http//:www.cast.uark.edu/ar_tourism/content/Lastfreelist.pdf (accessed on $21 / 03 / 2018$ )

Oppermann, M. (2000). Tourism destination loyalty. Journal of Travel Research, 39(1), 78-84

Pawaskar, P. \& Goel, M. (2014), A conceptual model: Multisensory marketing and destination branding, Symbiosis Institute of Management Studies Annual Research Conference (SIMSARC13), Procedia Economics and Finance, 11, 255-267.

Pike, S. (2009). Destination brand positions of a competitive set of near-home destinations. Tourism Management, $30(6), 857 \mathrm{e} 866$.

Pikkemaat, B., (2004). The measurement of destination image: The case of Austria. The Poznan University of Economics Review, 4(1), 87-102.

Preacher, K. J., \& Hayes, A. F. (2008). Asymptotic and resampling strategies for assessing and comparing indirect effects in multiple mediator models. Behavior research methods, 40(3), 879-891.

Qu, H, Kim, L. H. \& Kim, H. H. (2011). A model of destination branding: Integrating the concepts of the branding and destination image. Tourism Management, 32, 465-476.

Rewatkar, S. (2014). Factors Influencing Consumer Buying Behavior: A Review (with reference to Online Shopping).International Journal of Science and Research, 3(5), 1346-1349

Russell, J. A. \& Pratt, G. (1980). A Description of the Affective Quality Attributed to Environments. Journal of Personality and Social Psychology, 38(2), 311-22.

Russel, J. A., Ward, L. M. \& Pratt, G. (1981). Affective quality attributed to environments: a factor analytic study. Environment and Behavior, 13(3), 259-288.

Ryan, C., \& Gu, H. (2008). Destination branding and marketing: the role of marketing organizations. In H. Oh (Ed.), Handbook of hospitality marketing management (pp. 383-411). Oxford: Butterworth-Heinemann.

Stern, E. \& Krakover, S. (1993). The formation of composite urban image. Geographical Analysis, 25(2), 130146.

Tasei, A. D. A. \& Kozak, M. (2006). Destination brands vs destination images: do we know what we mean? Journal of Vacation Marketing, 12(4), 299-317.

Thompson, C. (1996). Caring Consumers: Gendered Consumption Meanings and the Juggling Lifestyle. Journal of Consumer Research, 22 (March), 388-407.

Uysal, M., Chen, J. \& Williams, D. (2000). Increasing state market share through a regional positioning. Tourism Management, 21(1), 89-96.

Weaver, D. B. \& Lawton, L. J. (2002). Overnight ecotourist market segmentation in the gold coast hinterland of Australia. Journal of Travel Research, 40(3), 270-280.

Woodside, A. G. \& Lysenko, S. (1989). A general model of travel destination choice. Journal of Travel Research, $27(4), 8-14$.

Yu, Y. \& Dean, A., (2001). The contribution of emotional satisfaction to consumer loyalty. International Journal of Service Industry Management, 12(3), 234-250.

Yvette, R. \& Turner, L. W. (2002). Cultural differences between Asian markets and Australian hosts. Journal of Travel Research, 40(3), 295-315.

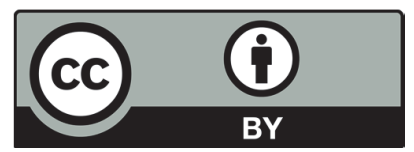

(C) 2018 by the authors; licensee Growing Science, Canada. This is an open access article distributed under the terms and conditions of the Creative Commons Attribution (CCBY) license (http://creativecommons.org/licenses/by/4.0/). 